\title{
QUÉ MAYOR PRIVILEGIO PUEDE HABER QUE ENSEÑAR
}

Daniel Pastor*

Qué mayor privilegio puede haber que enseñar.

Ser el primero en mostrar los huecos en la piedra donde viven las hadas; donde viven los monstruos.

Mostrar lo que está oculto y mostrar lo que siempre estuvo ahí, pero se ve distinto parado de manos.

Empujar, a tener el valor de caminar en la oscuridad, con los brazos por delante, dispuesto a abrazar, a tocar pared, a seguir caminando. Siempre riendo.

Qué mayor privilegio que marcar una vida.

El único mayor privilegio es haber sido ése al que le mostraron los huecos; ése al que pararon de manos; haber sido tocado por una mente y un corazón privilegiados; ser contagiado por esa hambre de conocimiento y emoción que te mantiene despierto de noche y soñando de día, $\mathrm{y}$ te hace quien eres hoy.

* Head of Managed Investments, Citi Wealth Management Latin America. 